\title{
ФОРМУВАННЯ СПОЖИВЧОЇ КУЛЬТУРИ В УЧНІВ НОВОЇ УКРАЇНСЬКОЇ ШКОЛИ
}

\author{
Надія Вовк \\ кандидат педагогічних наук, доцент кафедри педагогіки і методики \\ технологічної та професійної освіти \\ ДВНЗ «Донбаський державний педагогічний університет \\ м. Слов'янськ \\ nadiyavovk@ukr.net \\ Слизавета Шаповалова \\ магістрант спеціальності «Середня освіта», \\ спеціалізація «Трудове навчання та технології» \\ ДВНЗ «Донбаський державний педагогічний університет» \\ м. Слов'янськ \\ elizaveta1012@gmail.com
}

Анотація. У статті розглянуто роль споживчої культури у формуванні особистості учнів на уроках трудового навчання; зроблено аналіз програми трудового навчання відповідно до вимог Нової української школи. Визначено основні можливості трудового навчання у формуванні споживчої культури учнів Нової української школи. Обгрунтовано нагальність розвитку споживчої освіти як складової культури; окреслено пріоритетні напрями формування споживчої культури як фактора соціалізації школярів. Аргументовано актуальність вибору стратегії розвитку споживчої грамотності у формуванні творчого потенціалу учнів на уроках трудового навчання. Подано орієнтовну структуру формування споживчої культури учнів Нової української школи при реалізації проектно-технологічного підходу, моделювання ситуацій, проведення досліджень віртуальної лабораторії, кооперативного навчання; розглянуто орієнтовну тематику проектів і творчих, дослідницьких і ситуаційних завдань у процесі трудової діяльності.

Ключові слова: культура; споживання; споживча культура; проектування; трудове навчання; споживча грамотність; ситуаційні завдання.

Постановка проблеми в загальному вигляді. Розбудова громадянського суспільства, важливою умовою існування якого $\epsilon$ наявність грамотного активного споживача, неможлива без організації в масштабі всієї країни системного та комплексного впровадження споживчого виховання й навчання в усіх формах і на всіх рівнях загальної середньої освіти. Споживча освіта в Україні є однією з основних форм пристосування людей до нових і швидко змінюваних умов життя, заснованого на принципах ринкової економіки. Трудове навчання в умовах освітньої реформи орієнтовано на розвиток в учнів ключових і предметних компетентностей, які $є$ надзвичайно необхідними та важливими в формуванні споживчої культури в повсякденному житті людини.

Нова українська школа має бути школою для життя у XXI столітті. Змінюються технології, розвивається суспільство, тому необхідно перейти від 
школи, що дає дітям знання, які швидко застарівають, до школи компетентностей (поінформованість, обізнаність; competentia - у перекладі 3 латинської означає коло питань, у яких людина добре обізнана, має знання та досвід).

Найважливішими ключовими компетентностями, які необхідно формувати в учнів на уроках трудового навчання, $є$ :

- ініціативність $i$ nідприємливість. Уміння генерувати нові ідеї й ініціативи та втілювати їх у життя для підвищення як власного соціального статусу та добробуту, так і розвитку суспільства і держави. Уміння раціонально вести себе як споживач, ефективно використовувати індивідуальні заощадження, приймати доцільні рішення у сфері зайнятості, фінансів тощо;

- обізнаність $i$ самовираження у сфері культури. Здатність розуміти твори мистецтва, формувати власні мистецькі смаки, самостійно виражати ідеї, досвід та почуття за допомогою мистецтва. Ця компетентність передбачає глибоке розуміння власної національної ідентичності як підгрунтя відкритого ставлення та поваги до розмаїття культурного вираження інших;

- екологічна грамотність $i$ здорове життя. Уміння розумно та раціонально користуватися природними ресурсами в межах сталого розвитку, усвідомлення ролі навколишнього середовища для життя i здоров'я людини, здатність і бажання дотримуватися здорового способу життя;

- соиіальна та громадянська компетентності. Усі форми поведінки, які потрібні для ефективної та конструктивної участі в громадському житті, у сім’ї, на роботі. Уміння працювати з іншими на результат, попереджати і розв'язувати конфлікти, досягати компромісів. Повага до закону, дотримання прав людини i підтримка соціокультурного різноманіття [2, с. 12].

Зазначені компетентності складають основу споживчої культури підростаючого покоління. Саме тому в сучасної молоді необхідно сформувати споживчу грамотність, раціональну споживчу поведінку, що якнайкраще сприяє соціалізації майбутнього покоління.

Аналіз останніх досліджень і публікацій. Дослідженням питань формування споживчої культури в майбутнього покоління займалися Г. Григоренко, О. Гриценчук, Н. Кривошея, Д. Лазаренко, О. Лихолат, Л. Савченко, Н. Слюсаренко, З. Філончук й ін. Проте результатів комплексного вивчення та впровадження споживчої культури в освітній процес на сьогодні недостатньо.

Формулювання цілей статті. Тому, наше завдання - виділити в змісті трудового навчання комплекс знань, що відносяться до споживчих, i виявити педагогічно доцільну методику їхнього формування на уроках трудового навчання в умовах нової української школи.

Результати дослідження. Культуру споживання загалом можна визначити як сукупність матеріальних і духовних благ, знань, норм і цінностей споживчої поведінки, які встановилися в суспільстві. Культура споживання має динамічний 
процес, розвиток якого здійснюється на базі задоволення потреб у професійній діяльності, культурі, цінностях тощо. Це також надіндивідуальна реальність, що створюється людьми як безпосередньо, так і за допомогою соціальних інститутів: держави, бізнесу, навчання тощо. Гармонізація естетичних, пізнавальних і моральних потреб - необхідна умова формування культури споживання особистості.

Сучасному громадянину необхідно мати уявлення про основи споживання, про права споживачів, уміти застосовувати набуті знання в конкретних ситуаціях. Саме тому основні поняття про споживчі знання, про якість товарів і послуг важливо надавати учням загальноосвітньої школи. Постійне системне навчання учнів споживчим знанням суттєво впливає на вироблення в них розумної й адекватної поведінки в процесі споживання товарів і послуг.

Аналіз змісту оновленої програми 3 трудового навчання для учнів 5-9-их класів, затвердженої наказом МОН України від 07.06.2017 року, показав [4], що навчання орієнтовано на формування в учнів ключових i предметних компетентностей, що передбачені концепцією «Нової української школи». Ці компетентності покликані наблизити процес трудового навчання до життєвих потреб учня, його інтересів і здібностей, до можливості формування в учнів споживчих знань.

За програмою визначено компетентнісний потенціал трудового навчання та закладені наскрізні змістові лінії («Екологічна безпека та сталий розвиток», «Громадянська відповідальність», «Здоров’я і безпека», «Підприємливість і фінансова грамотність»). Усе це сприяє розвитку в учнів саме споживчих знань і вмінь, формуванню споживчої культури. Отримані знання і вміння кожен учень Нової української школи буде застосовувати у реальному житті, при цьому виконуючи практичні завдання, максимально наближені до життя.

Наприклад, учням пропонується проаналізувати етикетки різних товарів продовольчої групи: упаковки тістечок, печива чи інших товарів, використовуючи дидактичні та інформаційні картки, підручник (Табл. 1, 2). Результати виконаної роботи оформити в зошиті та зробити висновки.

Таблиця 1.

«Інформаційний захист під час купівлі продовольчих товарів»

Вимоги до інформації: доступність і повнота

\begin{tabular}{|l|l|}
\hline \multicolumn{1}{|c|}{ Вимога до інформації } & Наявність \\
\hline Назва харчового продукту & \\
\hline $\begin{array}{l}\text { Назва та повна адреса і телефон виробника, адреса потужностей (об’єкта) } \\
\text { виробництва. Для імпортних - назва, повна адреса і телефон імпортера }\end{array}$ & \\
\hline $\begin{array}{l}\text { Кількість нетто харчового продукту в установлених одиницях вимірювання } \\
\text { (вага, об’єм або поштучно) }\end{array}$ & \\
\hline $\begin{array}{l}\text { Склад харчового продукту в порядку переваги складників, зокрема харчових } \\
\text { добавок та ароматизаторів, що використовувались у його виробництві }\end{array}$ & \\
\hline
\end{tabular}

(ㄱ ДВНЗ «Донбаський державний педагогічний університет» 
Формування споживчої культури в учнів Нової української школи

\begin{tabular}{|l|l|}
\hline $\begin{array}{l}\text { Калорійність та поживна цінність із вказівкою на кількість білка, вуглеводів і } \\
\text { жирів у встановлених одиницях вимірювання на } 100 \text { г харчового продукту }\end{array}$ & \\
\hline $\begin{array}{l}\text { Кінцева дата споживання «Вжити до» або дата виробництва та строк } \\
\text { придатності }\end{array}$ & \\
\hline Номер партії виробництва & \\
\hline $\begin{array}{l}\text { Умови зберігання та використання, якщо харчовий продукт потребує певних } \\
\text { умов зберігання й використання для забезпечення його безпечності та якості }\end{array}$ & \\
\hline $\begin{array}{l}\text { Застереження щодо споживання харчового продукту певними категоріями } \\
\text { населення (дітьми, вагітними жінками, літніми людьми, спортсменами та } \\
\text { алергіками), якщо такий продукт може негативно впливати на їх здоров’я у } \\
\text { разі його споживання }\end{array}$ & \\
\hline
\end{tabular}

Таблиця 2.

Достовірність - вказана на етикетці інформація має бути правдивою

\begin{tabular}{|l|l|}
\hline \multicolumn{1}{|c|}{ Критерії перевірки } & Стан інформації (правдива чи ні) \\
\hline Штрих-код & \\
\hline Індекс Е & \\
\hline Позначка ГМО & \\
\hline Знаки відповідності & \\
\hline Екомаркування & \\
\hline
\end{tabular}

Алгоритм роботи:

1) підібрати етикетки продовольчих товарів;

2) дослідити етикетки за вищевказаними критеріями;

3) узагальнити результати дослідження, визначивши загальний стан етикеток і зауваження до них;

4) оформити результати роботи в зошиті;

5) сформулювати поради споживачам щодо придбання продовольчих товарів.

Програма грунтується на основі проектно-технологічної діяльності учнів, але змінено підходи до опанування змісту цієї діяльності на уроках трудового навчання: формування змісту технологічної діяльності здійснюється на основі об'єктів проектної діяльності, а не технологій, зокрема вибір теми проекту (виробу для виготовлення) і добір та вивчення відповідних технологій обробки матеріалів.

На уроках трудового навчання учням можна запропонувати такі теми проектів: «Придбання товарів через Інтернет», «Раціональне споживання в 
межах споживчої культури» тощо. Проте найбільший інтерес викликають інтегровані міжпредметні проекти, наприклад, технологія + ОБЖ; технологія + екологія, технологія + біологія. Це дослідження або інформаційні проекти, теми яких пропонують самі учні: «Бюджет шкільних витрат» (Скільки необхідно грошей, щоб зібрати дитину в школу?); «Технології XXI століття» (Які технології подарувало нам XXI століття?), «Роль комп’ютера в житті людини»; «Чисте місто» (боротьба із засміченням території міста); «Жива вода» (вивчення якості послуг водопостачання в рідному місті); «Я купую взуття» (аналіз ринку взуття та його якісних ознак); «Споживчий кошик» (порівняння цін споживчого кошика поточного та минулого року, сімей із різним достатком, різних міст i районів); «Я купую холодильник» (вивчення поведінки споживача під час купівлі побутової техніки для зберігання харчових продуктів); «Оплата комунальних послуг» (вивчення тарифів і розрахунків на комунальні послуги).

За програмою передбачена академічна свобода вчителя трудового навчання. Учитель обирає (разом з учнями) об'єкти проектно-технологічної діяльності; визначає кількість проектів для кожного класу (з урахуванням вимог програми); визначає кількість годин на виконання кожного проекту (з урахуванням складності технологіï); визначає теми уроків з опанування обраних проектів; розкриває зміст тем, що планує для вивчення, з урахуванням змісту очікуваних результатів за трьома компонентами: знаннєвим, діяльнісним i ціннісним.

Під час проектування та виготовлення виробу в учнів формується проектно-технологічна компетентність: здатність учня застосовувати знання, уміння, навички в процесі створення і виготовлення виробу (послуги) - від творчого задуму до практичного використання готового виробу, виготовленого за обраною технологією. А також $є$ можливість формувати в учнів споживчі знання та згрупувати їх за видами: матеріалознавчі, технологічні, економічні, знання про споживчі властивості матеріалів і виробів.

Виконання завдань із проектування сприяє формуванню в учнів таких складових споживчої культури:

1. Правової та споживчої грамотності - формування поваги до закону, а також почуття самоповаги та впевненості у своїх власних силах, здатності вільно орієнтуватися документах, що регламентують права та обов'язки споживачів, формування власного світогляду, здатності нести відповідальність за прийняті рішення.

2. Інформаційно-цифрової компетентності - здатність отримувати своєчасну та достовірну інформацію про придбані товари та послуги для забезпечення свідомого й раціонального вибору, уміння аналізувати інформацію від виробника через найпоширеніші маркування.

3. Раціональності - уміння оцінювати якісні та кількісні показники товарів i послуг для максимального задоволення своїх потреб, здатність визначати альтернативну вартість свого вибору, здатність до збалансованого споживання. 
Формування споживчої культури в учнів Нової української школи

4. Активності - здатність зважено відстоювати свої права споживача, здійснювати раціональний вибір, сприяти поліпшенню якості обслуговування.

5. Комунікативності - здатність до побудови ефективних комунікацій у процесі захисту своїх прав споживача, здатність до формування культури споживчої поведінки.

Результатом проектування буде усвідомлення учнями того, що якість життя - один із ключових чинників національної конкурентоспроможності, яка формується їхньою свідомою споживчою поведінкою.

Під час роботи над проектами для формування в учнів споживчих знань ми запропонували використовувати один із методів стимуляції розвитку пізнавальних процесів - метод відкриття нового у відомому. Для цього доцільним буде використання творчих завдань, що сприятимуть не лише загальному розвитку особистості учнів, а й формуванню культури споживання, логічному та критичному мисленню. Це можуть бути моделювання ситуацій, віртуальні лабораторії, проведення досліджень, кооперативне навчання, ділові ігри тощо. Наприклад:

- моделювання ситуацій. «Ми купуємо в магазині, кіоску, на ринку». Продемонструй процес продажу-купівлі товару (кросівок, цукерок, фруктів). Продемонструй практичні навички культурної споживчої поведінки під час здійснення покупки товарів і послуг (І група - купує в магазині, II група - робить зачіску в перукарні, III група - завітала до торгового центру);

- віртуальна лабораторія. Створення реклами товарів і послуг; власної етикетки; каталогу товарів і послуг; проекту дитячого кафе тощо.

- дослідження. Завдання: робота із джерелами інформації, обробка статистичної інформації. Порахуй, скільки разів упродовж 30 хвилин демонструвалася реклама по телебаченні. Назви, які товари, послуги рекламувалися. Прокоментуй, реклама якого товару, послуги тобі сподобалася найбільше.

Отже, використання творчих завдань на уроках трудового навчання, спрямованих на формування культури споживання в учнів, значно активізує їхню інтелектуальну активність, не в останню чергу за рахунок збільшення ролі асоціацій у розумовій діяльності. При цьому акцент у пізнавальному процесі переноситься 3 пасивного на активне сприйняття навчального матеріалу. Результатом роботи учнів над творчими завданнями стають створені та закріплені у свідомості учнів образи, що і можна віднести до одного з видів творчої уяви.

Пізнавальні процеси завжди мають мету i засоби досягнення та передбачають перетворення предмета на результат. Для розвитку в учнів умінь пізнавати світ, як відмічає Б. Бім-Бад [1] (услід за Н. Виноградовою), необхідно вчити їх визначати мету пізнання, знаходити засоби, які допоможуть швидко та легко справитися з поставленими завданнями, співвіднести з ними процес своєї діяльності, а також оцінити отриманий результат. Це вибіркова спрямованість на 
окремі об'єкти, яка пов'язана 3 позитивним емоційним відношенням, пізнавальною активністю та вольовим зусиллям суб'єкта. Він підкреслює, що для появи живого пізнавального інтересу в школярів під час навчальної діяльності необхідно використати той досвід, який у них $\epsilon$, ті знання, які вони отримали в процесі життя стихійно, несвідомо. Адже власна позиція дитини, спрямування іiі до самостійної діяльності відіграють особливу роль у пізнавальному інтересі, розвитку його широти та стійкості.

Відповідно до цього ми запропонували використовувати метод стимуляції розвитку пізнавальних процесів - відкриття нового у відомому. Цей метод передбачає врахування й інших методів навчання: пояснення, розповідь, бесіда, завдання тощо, які в цьому випадку виступають як прийоми навчання, що дають можливість на уроці розглянути цікаві проблеми, викликати захоплення в дітей, досягти зростання пізнавальної активності кожного учня.

Так, для реалізації цього методу на уроках трудового навчання учням доцільно пропонувати вирішення ситуачійних завдань різної складності. Наприклад: дайте правильну і найбільш повну відповідь відповідно до положень Закону України «Про захист прав споживачів».

Правилами продажу окремих видів товарів.

Час написання - 45 хв.

Разом можна набрати 30 балів.

Ситуація 1. (4 б.)

Поліна на літньому розпродажу в магазині модного молодіжного одягу «Твоє» придбала трикотажну сукню. Оскільки це була не перша покупка подібної речі цієї фірми, Поліна взяла іiі, не особливо ретельно вибираючи. Одягнувши сукню перший раз, вона виявила, що після носіння на тілі залишаються сліди фарби. У магазині товар не прийняли, бо він був куплений під час розпродажу.

Питання. Може Поліна вимагати обмін товару на аналогічний, якщо 3 моменту покупки пройшло менше двох тижнів?

Ситуація 2. (6 б.)

Антон замовив по системі «Товари поштою» і придбав факсимільний апарат американського виробництва. До посилки був запропонований переклад інструкції українською мовою. При спробі підключити апарат перегорів виявилося, що приєднати до джерела енергії блок живлення можна було лише через спеціальний трансформатор, бо в нашій мережі напруга більш висока, ніж у США. На пошті прийняти претензію відмовилися, мотивуючи це тим, що займаються лише доставкою товарів.

Питання. Які вимоги і кому може пред'явити Антон?

Ситуація 3. (4 б.)

Під час лікування Вікторії в платній стоматологічній поліклініці лікар, який проводив операцію імплантації (яка проводиться під наркозом), поставив імплант німецького виробництва вартістю 150 грн. замість вітчизняного за 
55 грн., як було сплачено при укладенні договору. Після операції ій запропонували доплатити 95 грн., мотивуючи це тим, що поставлений їй імплант кращої якості та надійніше вітчизняного аналога.

Питання. Які дії слід прийняти Вікторії?

Ситуація 4. (6 б.)

Вероніка придбала туфлі в салоні елітного взуття італійського виробництва 3 терміном гарантії 8 місяців. Через три місяці підошва в туфель відклеїлася. Коли Вероніка звернулася до магазину з гарантійним талоном i проханням про безкоштовний ремонт, їй було відмовлено 3 посиланням на те, що взуття елітне і призначено виключно як капці в приміщенні, про що Вероніка була письмово попереджена, але носила ї на вулиці i в громадському транспорті. Вероніка 3 цим рішенням не згодна, бо істотний недолік і виник, насамперед, із вини виробника.

Питання. Хто правий у цій ситуації і чому?

Ситуація 5. (10 б.)

Сергій придбав комбінований агрегат газонокосарку-пилосос «Арієнс». При купівлі була надана інформація про те, що агрегат здійснює прибирання листя 3 газону і дрібних гілок. Однак при експлуатації з'ясувалося, що машина здатна засмоктувати тільки хвою, що обсипалась, та листя чагарників і берез. При спробі зібрати кленове та каштанове листя агрегат забивався і припиняв роботу.

Питання. Чи може Сергій вимагати повернення грошей за куплений агрегат?

Головним способом залучення учнів до діяльності на уроці є перевірка, або aydum - спеціальне завдання із самостійного дослідження учнем власного стилю життя, аналіз наявного досвіду за допомогою запитань або дій, запропонованих у посібнику. Інформація, отримана під час виконання аудиту, ініціює дискусію, обговорення, $є$ способом входження учнів у тему [5, с. 24].

Першорядне питання, на яке відповідають школярі в результаті такого самовивчення, - яким $є$ мій власний вплив на навколишнє середовище? Продовження досліджень уможливлює поступове усвідомлення концепції: «Мої розумні дії принесуть користь не лише суспільству, природі, але й мені».

Отже, можна виділити алгоритм самодослідження учнів у різних темах трудового навчання: 1) аудит; 2) осмислення проблеми (чому це $\epsilon$ проблемою для мене, мого оточення); 3) збір інформації щодо проблеми та наявних у світі способів її розв'язання; 4) визначення цілей (чого хочу досягти); 5) формування намірів і плану дій; 6) реалізація плану; 7) перевірка результатів, оцінка; 8) плани на майбутнє [6].

Так, суть нової парадигми навчання полягає в тому, що навчальний процес відбувається лише шляхом постійної активної діяльності та взаємодії всіх учнів. Це співнавчання, взаємонавчання, де й учень, і вчитель $є$ рівноправними, рівнозначними суб'єктами навчання, які усвідомлюють, що і для чого вони 
роблять, прогнозують свою діяльність та їі результати, рефлексують із приводу того, що вони знають, уміють і здійснюють.

Висновки з дослідження та перспективи подальших розвідок у цьому напрямі. У процесі дослідження ми встановили:

1. Сучасне суспільство, ринок праці, соціальні перетворення вимагають від системи освіти нових підходів і знань, що сприяють формуванню свідомого, підготовленого до нових викликів громадянина, здатного жити та діяти в сучасному світі, що швидко змінюється. Споживча освіта вбачається невід'ємною складовою, яка дозволяє формувати стале, демократичне та розвинуте громадянське суспільство й громадян, здатних його розвивати та успішно взаємодіяти. Але проблема формування окремих споживчих знань в учнів, зокрема на уроках трудового навчання, залишається ще недостатньо розробленою.

2. Вивчення змісту трудового навчання в 5-9 класах дозволило визначити можливості формування в учнів загальноосвітньої школи цілого комплексу споживчих знань. Цей комплекс містить групи знань за видам, а саме: товарознавчі, технологічні, матеріалознавчі, економічні та знання про споживчі властивості матеріалів і виробів. Основним методом формування в трудовому навчанні знань, які належать до споживчих, $є$ метод стимуляції розвитку пізнавальних процесів, а саме: відкриття нового у відомому.

3. Дослідження формування знань в учнів на уроках трудового навчання, які відносяться до споживчих, за допомогою методу відкриття нового у відомому показало достатньо високу його педагогічну доцільність. Отримані в результаті дослідження дані засвідчили педагогічну ефективність запропонованої нами методики, завдяки якої в учнів збільшилась активність у навчальній діяльності, а також підвищився інтерес як до знань, які в трудовому навчанні належать до споживчих, так і до самого трудового навчання.

\section{СПИСОК ВИКОРИСТАНИХ ДЖЕРЕЛ}

1. Бим-Бад, Б. М. (б.д.). Мир постепенно окружает нашу школу. Взято с http://www.bim-bad.ru/biblioteka/article_full.php?aid=1155\&binn_rubrik_pl_articles=164.

2. Концепція «Нова українська школа. (2016, 27 жовтня). Взято 3 http://mon.gov.ua/activity/education/zagalna-serednya/ua-sch-2016/konczepcziya.html

3. Лихолат, О. (2011). “Основи споживчих знань” в циклі підготовки вчителя технології, спеціалізація “Основи домашнього господарювання”. Науковий часопис НПУ імені М. П. Драгоманова. Серія 5. Педагогічні науки: реалії та перспективи, 30, 120-125.

4. Навчальна програма з трудового навчання 5-9 класи для загальноосвітніх навчальних закладів затверджена наказом МОН. № 804. (2017, 6 липня). Взято 3 https://www.edera.com/img/books/mon59/programs/2.trudove-navchannya-5-9.pdf.

5. Пометун, О.І., Пилипчатіна, Л. М. і Сущенко, І. М. (2013). Уроки для сталого розвитку : посібник для вчителя з навчального курсу за вибором для учнів 8-го класу загальноосвітніх шкіл. Дніпро, Україна: «ЛІРА».

6. Теличко, Н.В. (2012). Роль педагогічного емпауерменту у формуванні педагогічної майстерності вчителів початкової школи. Науковий вісник Ужгородського національного університету. Серія «Педагогіка. Соціальна робота», 28, 168-171. 
Формування споживчої культури в учнів Нової української школи

\title{
ФОРМИРОВАНИЕ ПОТРЕБИТЕЛЬСКОЙ КУЛЬТУРЫ У УЧАЩИХСЯ НОВОЙ УКРАИНСКОЙ ШКОЛЫ
}

\author{
Надежда Вовк \\ кандидат педагогических наук, старший преподаватель
}

ГВУЗ «Донбасский государственный педагогический университет»

г. Славянск, Украина

nadiyavovk@ukr.net

Елизавета Шаповалова

магистрант специальности «Среднее образование», специализация «Трудовое обучение и технологии»

ГВУЗ «Донбасский государственный педагогический университет»

\author{
г. Славянск, Украина \\ elizaveta1012@gmail.com
}

Аннотация. В статье рассмотрена роль потребительской культуры в формировании личности учащихся на уроках трудового обучения, сделан анализ программы трудового обучения в соответствии с требованиями новой украинской школы. Определены основные возможности трудового обучения в формирование потребительской культуры учащихся новой украинской школы. Обоснованно актуальность развития потребительского образования как составляющей культуры, определены приоритетные направления формирования потребительской культуры как фактора социализации школьников. Аргументированно актуальность выбора стратегии развития потребительской грамотности в формировании творческого потенциала учащихся на уроках трудового обучения. Подано ориентировочную структуру формирования потребительской культуры учащихся новой украинской школы при реализации проектно-технологического подхода, моделирования ситуаций, проведения исследований виртуальной лаборатории, кооперативного обучения, рассмотрены ориентировочную тематику проектов и творческих, исследовательских и ситуационных задач в процессе трудовой деятельности.

Ключевые слова: культура; потребление; потребительская культура; проектирование; трудовое обучение; потребительская грамотность; ситуационные задачи.

\section{DEVELOPING STUDENTS' CONSUMER CULTURE IN NEW UKRAINIAN SCHOOL}

\author{
Nadiia Vovk \\ Candidate of Pedagogical Sciences, Associate Professor \\ SHEE "Donbas State Pedagogical University" \\ Sloviansk, Ukraine \\ nadiyavovk@ukr.net \\ Yelyzaveta Shapovalova \\ Master Student of specialty "Secondary Education", \\ specialization "Handmade Craft and Technologies" \\ SHEE "Donbas State Pedagogical University" \\ Sloviansk, Ukraine \\ elizaveta1012@gmail.com
}




\begin{abstract}
The article reveals the key competences that form the basis of consumer culture of young generation. That's why the issue of developing consumer literacy and rational consumer manners, which provide socialization for young generation, is relevant. H. Hryhorenko, O. Hryshenchuk, N. Kryvosheia, D. Lazarenko, O. Lykholat, L. Savchenko, N. Sliusarenko, and Z. Filonchuk devote their research to studying the issues of developing consumer culture of young generation. But the authors prove that there is a lack of complex studying and implementing consumer culture into educational process. The purpose of the article is to pick out in the content of craft education the set of knowledge that concern the consumption and highlight the methodology of their developing in the lessons of handcrafts in New Ukrainian School.

In the article the authors examine the role of consumer culture in shaping the student personality in the lessons of craft education, analysis of the curriculum of craft education in accordance with the requirements of New Ukrainian School. The basic opportunities of craft training in development of the students' consumer culture of new Ukrainian school are determined. The necessity of developing consumer education as a component of culture is proved, priority directions of developing consumer culture as a factor of schoolchildren's socialization are outlined. The relevance of choosing a strategy for developing consumer literacy in the development of students' creative potential at the lessons of craft education is argued. The approximate structure of the development of the students' consumer culture at New Ukrainian School in the implementation of the design and technological approach, situation simulation, research of the virtual laboratory, cooperative learning, the approximate themes of the projects and creative, research and situational tasks in the process of labor activity are considered.
\end{abstract}

Key words: culture; consumption; consumer culture; designing; craft training; consumer literacy; situational tasks.

\title{
REFERENCES (TRANSLATED AND TRANSLITERATED)
}

1. Bim-Bad, B. M. (n.d.). World is gradually surrounding our school. Retrieved from http://www.bim-bad.ru/biblioteka/article_full.php?aid=1155\&binn_rubrik_pl_articles=164.

2. Concept "New Ukrainian school". (2016, October 27). Retrieved from http://mon.gov.ua/activity/education/zagalna-serednya/ua-sch-2016/konczepcziya.html.

3. Lykholat, O. (2011). "Basis of costomer knowledge" in the cycle of technology teachers' training, specialty "Basis of housekeeping. Naukovyi chasopys NPU imeni M. P. Drahomanova. Seriia 5. Pedahohichni nauky: realii ta perspektyvy: zb. naukovykh prats, 30, 120-125.

4. Curriculum of handicraft education for forms 5-9 in comprehensive schools. \#804. (2017, June 7). Retrieved from https://www.ed-era.com/img/books/mon59/programs/2.trudovenavchannya-5-9.pdf.

5. Pometun, O. I., Pylypchatina, L. M., \& Sushchenko, I. M. (2013). Lessons for sustained development: a manual for teachers in a subject chosen by students of the $8^{\text {th }}$ form of comprehensive school. Dnipro, Ukraine: «LIRA».

6. Telychko, N. V. (2012). The role of pedagogical empowerment in developing primary school teachers' pedagogical mastership. Naukovyi visnyk Uzhhorodskoho natsionalnoho universytetu. Seriia «Pedahohika. Sotsialna robota», 28, 168-171.

Матеріали надійшли до редакції 01.12.2018 р. 